\title{
Development and evaluation of a virtual patient-centered outcomes research training program for the cystic fibrosis community
}

Emily M. Godfrey ${ }^{1 *} \mathbb{D}$, Erin K. Thayer ${ }^{1}$, Laura Mentch², Traci M. Kazmerski ${ }^{3}$, Georgia Brown $^{2}$, Molly Pam² and Morhaf Al Achkar ${ }^{1}$

\begin{abstract}
Background: Patient-centered outcomes research (PCOR) emphasizes patient-generated research priorities and outcomes, and engages patients throughout every stage of the research process. In the cystic fibrosis (CF) community, patients frequently provide input into research studies, but rarely are integrated onto research teams. Therefore, we developed and evaluated a virtual pilot PCOR training program to build PCOR capacity in the CF community (patients, caregivers, researchers, nonprofit stakeholders and providers). We aimed to show changes among participants' perceived PCOR knowledge (a.k.a PCOR knowledge), confidence in engaging stakeholders, and post-training session satisfaction.
\end{abstract}

Methods: Guided by a prior CF community educational needs assessment, our researcher and patient-partner team co-developed a four-part virtual online training program. We structured the program towards two learner groups: patients/caregivers and researchers/providers. We evaluated participants' $P C O R$ knowledge, confidence in engaging stakeholders, and session satisfaction by administering 5-point Likert participant surveys. We tested for significant differences between median ratings pre- and post-training.

Results: A total of 28 patients/caregivers, and 31 researchers/providers participated. For both learner groups, we found the training resulted in significantly higher PCOR knowledge scores regarding "levels of engagement" $(p=.008)$. For the patient/caregiver group, training significantly increased their PCOR knowledge about the barriers/enablers to doing PCOR ( $p=.017)$, effective PCOR team elements $(p=.039)$, active participation $(p=.012)$, and identifying solutions for successful PCOR teams $(p=.021)$. For the researcher/healthcare provider group, training significantly increased participants' ability to describe PCOR core principles $(p=.016)$, identify patient-partners $(p=.039)$, formulate research from patient-driven priorities $(p=.039)$, and describe engagement in research grants $(p=.006)$. No learner group had significant changes in their confidence score. Most participants were either "satisfied" or "very satisfied" with the training program.

Conclusions: Overall, our virtual pilot PCOR training program was well received by patients, caregivers, researchers and providers in the CF community. Participants significantly improved their perceived knowledge with core PCOR learning items.

Trial registration Retrospectively registered at clinicaltrials.gov (NCT04999865).

*Correspondence: godfreye@uw.edu

${ }^{1}$ Department of Family Medicine, School of Medicine, University of Washington, 431111 th Ave NE, Box 354982, Seattle, WA 98105, USA

Full list of author information is available at the end of the article original author(s) and the source, provide a link to the Creative Commons licence, and indicate if changes were made. The images or other third party material in this article are included in the article's Creative Commons licence, unless indicated otherwise in a credit line to the material. If material is not included in the article's Creative Commons licence and your intended use is not permitted by statutory regulation or exceeds the permitted use, you will need to obtain permission directly from the copyright holder. To view a copy of this licence, visit http://creativecommons.org/licenses/by/4.0/. The Creative Commons Public Domain Dedication waiver (http://creativeco mmons.org/publicdomain/zero/1.0/) applies to the data made available in this article, unless otherwise stated in a credit line to the data. 
Keywords: Cystic fibrosis, Co-development, Education, Evaluation, Patient-centered outcomes research, Patient involvement, Patient engagement, Training

\section{Plain English Summary}

Cystic fibrosis (CF) is a rare, genetic disease; meaning people are born with the disease and have it throughout their lives. CF is a multi-system disease, primarily affecting the respiratory system. Daily care for people with CF (PwCF) includes taking many medications and breathing treatments. Many PWCF have experienced participating in research as research subjects, but not as partners on research teams participating as experts with the lived experience. Including patient and caregiver partners on research teams is important to improve quality of research. By working alongside each other, patient and/or caregiver partners and researchers build trust. Together, they pursue research questions deemed most important to patients and through this inclusive process, study findings are more rapidly adapted by patients and their communities. We found in a prior survey that $85 \%$ of patients, caregivers, healthcare providers and researchers in the CF community wanted training on how to include patient partners onto research teams. Our researcher and patient-partner team co-developed a four-part virtual pilot online training program focused on how to integrate patients/caregivers into research teams. This study aims to show changes in participants' perceived knowledge, confidence in engaging stakeholders and satisfaction after participating in our training program. Participants included patients, caregivers, researchers and health care providers. We found that our training program improved knowledge about patient-engaged principles for all participants. This training program stands ready to serve as a model for further development to help increase capacity around patient and stakeholder engagement on research teams in the CF community.

\section{Background}

More than 30,000 people in the United States have cystic fibrosis (CF), which is a rare, life-shortening, multi-organ disease that can lead to severe respiratory and digestive problems as well as other complications such as infections and diabetes [1]. Until fairly recently, most persons affected by CF were children, but today, with increased medical interventions, more than $50 \%$ of people with $\mathrm{CF}$ (PwCF) are adults with a median survival of almost 45 years [1]. The CF community is widely recognized for its long-standing tradition of including PwCF and families to help shape research affecting their community [2,3]. However, this patient participation has been limited to only discrete parts of the research process, such as participating on data safety monitoring boards, prioritizing research topic areas, providing feedback on study questionnaires or reviewing grant proposals. While this level of involvement, according to the spectrum of patient/stakeholder engagement, allows patients to provide input, it falls short of genuine engagement and partnership with researchers [4]. Part of what makes bringing $\mathrm{PwCF}$ together onto research teams so difficult are strict infection control guidelines that restrict in-person contact between patients to avoid the spread of deadly pathogens [5]. This is especially problematic for traditional methods of patient engagement, which are mostly geared for "in-person" group interactions.

Patient-centered outcomes research (PCOR), or patient and public involvement (PPI), entails meaningfully engaging patients, caregivers and other stakeholders (such as clinicians, payers and policy makers) throughout the research process and is increasingly gaining traction among research teams in the United States [6]. Patients, in particular, are valuable to include on research teams because they provide expertise in living daily with their disease. Ideally, research teams using PCOR methodology invite patients as partners to bring ideas and questions based on their lived experience, with researchers then sharing a variety of possible approaches to study them. With this exchange, patient-partners begin to understand the research process more fully and can move towards authentically participating in all phases of research. PCOR has shown to improve research quality, increase patient trust in both the research and researchers, and positively affect health outcomes [6-8].

The process of inviting patients as full partners onto research teams requires a cultural shift among researchers who prize efficiencies, and rarely have to contend with diverse perspectives, new unconventional possibilities, or members of the team who are unfamiliar with research terms and processes [9]. For researchers and patients who want to learn about PCOR, training is available. Current PCOR training curricula, however, do not address certain cultural aspects unique to the CF community. For example, power dynamics exist in all areas of medicine, but the hierarchical patient-doctor relationship in CF is considered to be especially apparent because of the life-long and complex nature of the disease [10, 11]. Clinicians are unsure how to ask patients to serve as partners without patients feeling a sense of obligation [12]. 
Additionally, as a rare disease, PwCF, caregivers, clinicians and researchers tend to already know one-another, and thus the change from role as patient to patient-partner is more difficult. For example, when we first started our PCOR team, patient partners were reluctant to speak freely in front of researchers and clinicians due to the fear that something they would say would get back to their personal clinician [13]. This made patients want to keep their discussions confidential. Thus, based on our prior needs assessment, we found the most important training areas to address for both the patient/caregiver and provider/researcher groups included: (1) knowing the time commitment required to learn PCOR methodology, and (2) learning how to develop and maintain trust when patients/caregivers are active members of the research team [14]. PCOR training is necessary to achieve a critical mass of researchers employing this methodology. Additionally, more research funders require stakeholder engagement on grant submissions. This study aims to evaluate a virtual training adapted for the CF community on perceived PCOR knowledge acquisition, confidence in engaging stakeholders and satisfaction of the training program.

\section{Methods}

We report this study according to the GRIPP2 guidelines in the reporting of patient and public involvement (PPI) in research [15]. We report as many elements on the checklist as relevant to this study.

\section{Design}

We employed a qualitative descriptive design to co-develop four training sessions with patient and advocacy organization stakeholders using a framework adapted from the Model for Improvement [16]. The Model for Improvement framework uses four iterative phases (1) Plan, (2) Do, (3) Study, (4) Act (see Fig. 1) [16]. Our focus for this present study were phases (2) and (3). Phase 1 (Plan) included a needs assessment coproduced and conducted by our team, which has been published previously [14].

\section{Setting}

This study was conducted virtually using Zoom for synchronous meetings and training sessions, Slack and email for asynchronous communications between team members, and Google Docs for document sharing. The origins of this co-production patient-engaged team came from the Cystic Fibrosis Reproductive and Sexual Health Collaborative (CFReSHC, cfreshc.org). CFReSHC is a U.S-based, nationwide, English-speaking, online patient-driven collaborative committed to responding to research gaps articulated by adult PwCF. In 2018, having built a successful patient-engagement structure, members of CFReSHC wanted to build PCOR capacity within the greater CF community. CFReSHC researcher and patient members co-wrote a successfully funded grant application to the PatientCentered Outcomes Research Institute (PCORI) to conduct a needs assessment and develop and evaluate an educational PCOR training program for PwCF, researchers and health care providers. CFReSHC is hosted by the University of Washington Department of Family Medicine.

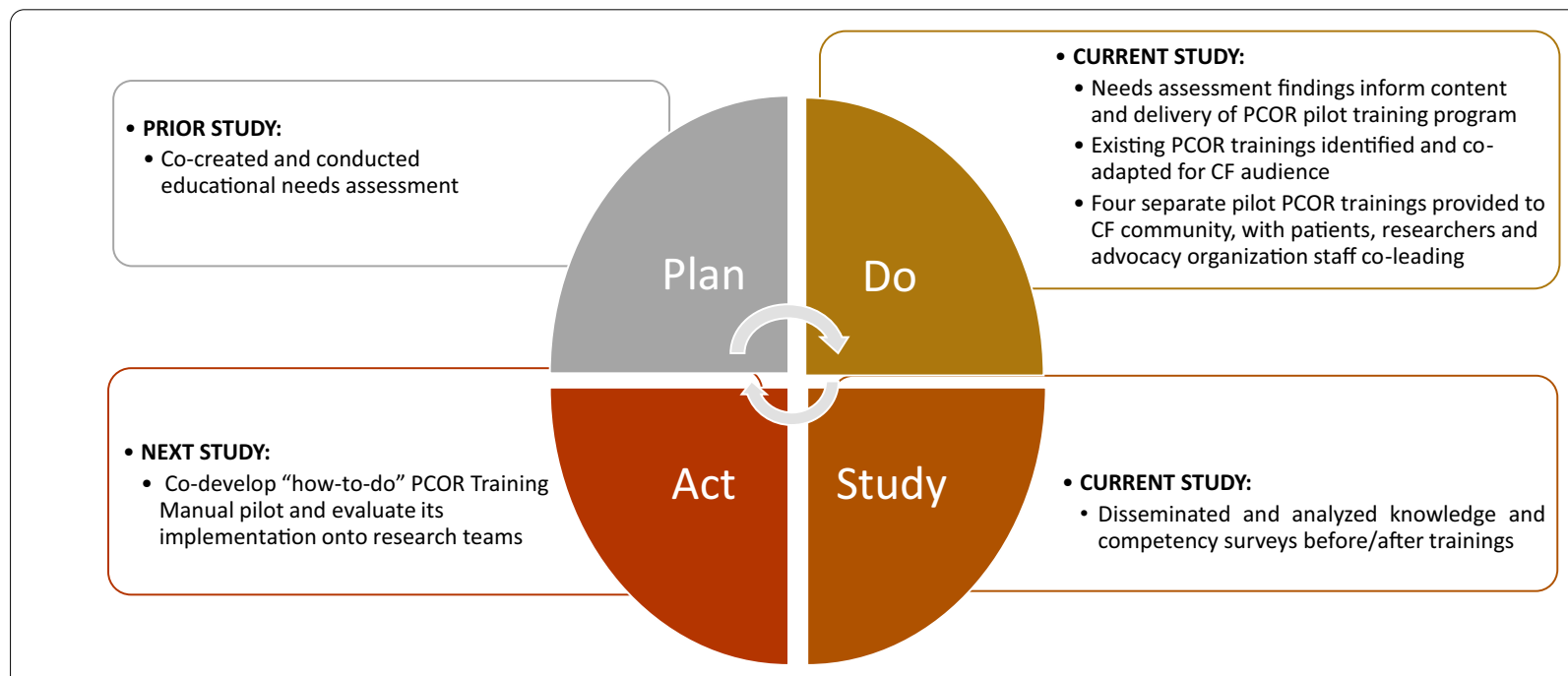

Fig. 1 Adapted Model For Improvement framework to build patient-centered outcomes research capacity in the cystic fibrosis community 


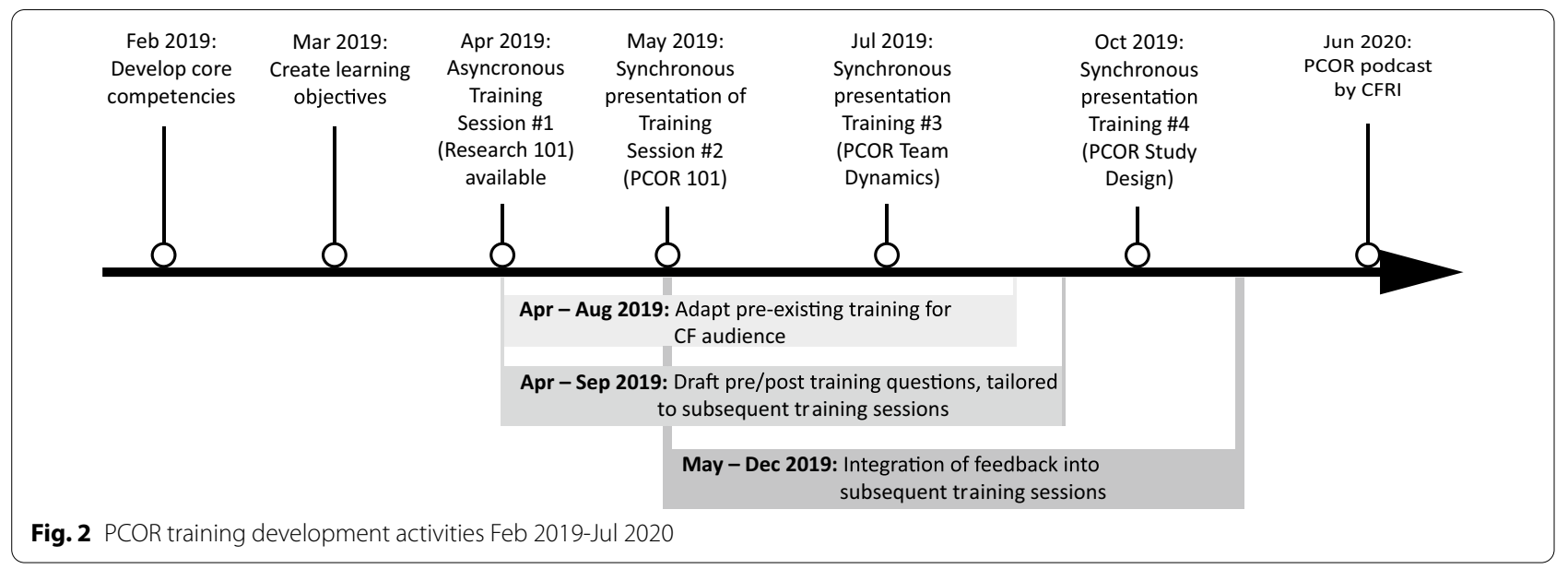

\section{Training co-developers: participant characteristics}

The training development and evaluation team consisted of several different types of stakeholders, including clinician-researchers $(n=3), \operatorname{PwCF}(n=3)$, public health researcher $(n=1)$ and a CF advocacy organization staff member $(n=1)$. The project team was led by a CFReSHC co-founder and a practicing family physician and clinician-researcher with patient engagement methodological expertise. A second clinician-researcher specialized in CF, and the third clinician-researcher was an expert in educational design and evaluation. Project coleads included three current CFReSHC patient-partners: (1) one with a career as a sexual health educator and trainer, (2) another with CF community advocacy connections, and (3) another with experience in media and marketing. Our community advocate was a staff member for the largest non-for-profit organization in the CF community in the United States, the Cystic Fibrosis Foundation (CFF). A Master-level student in the University of Washington School of Public Health managed the team and performed the data analysis.

\section{Training program development}

We developed, led and evaluated four separate pilot trainings between February 2019 and August 2020. Members of the development/evaluation team met weekly throughout the study period. The team's activities are depicted in the timeline in Fig. 2, which were guided by best practices for training and development provided by the University of Washington Institute of Translational Health Sciences [17]. Our initial steps included developing four core competencies and learning objectives for each competency, informed by findings from a prior $\mathrm{CF}$ community educational needs assessment [14]. Over the course of several weeks, the team co-created four separate core competencies for two distinct learner groups:
(1) researchers/providers and (2) patients/caregivers. We iteratively developed 3-6 learning objectives within each core competency using Bloom's taxonomy until consensus was reached by all team members [18]. To create the training format, we applied the key adult learning principles, which included pre-training materials, learning aids, and multi-modal learning strategies (e.g., didactics, small group activities, case scenario discussions, and question/ answer sessions) $[19,20]$. The public health researcher and a patient-partner with sex-education experience then collaboratively scouted the internet for existing PCOR training programs with materials or items that met our learning objectives (see Appendix 1). The patient-partner with CF advocacy organizations connections sought preexisting training programs already available for the $\mathrm{CF}$ community. At each weekly meeting, the public health researcher and patient-partners would present powerpoint slides or material they found on the internet, and the remaining team members adapted these to meet items specifically mentioned during our needs assessment [14]. The public health researcher and two patientpartners additionally identified information from the peer-reviewed literature on PCOR, which supplemented aspects of the CF-specific training program that had not been identified in pre-existing PCOR training [21-29]. The literature was reviewed by the clinician-researchers and the educational specialist. Because in-person contact between patients with CF is restricted, we included information about the use of web-based platforms for virtual PCOR collaborations based on an in-depth interview study performed by our team [30].

\section{Data collection}

Once the materials to conduct a training session were finalized, we co-led the online PCOR training program with participants from the CF community throughout 
the United States. We invited adults with CF and their caregivers, CF providers, researchers and research staff to participate in and provide feedback about our training sessions. We advertised the training through CFReSHC, CFF, Cystic Fibrosis Research Institute (CFRI), and the University of Washington. The patient-partner with marketing skills created recruitment flyers for each training and widely advertised the training throughout the CF community. Participants who attended a training session and completed the surveys were provided a $\$ 15$ gift card.

All team members helped conduct four separate pilot PCOR training sessions between April 2019 and October 2019. We evaluated each training session by administering a survey to participants before and immediately after the training session, except for Training 1, where we surveyed participants only after the training. The survey questions asked participants to rate their agreement about their own perceived PCOR knowledge (a.k.a PCOR knowledge), confidence with engaging stakeholders and training session satisfaction (post-training only) using a 5-point Likert scale. At the end of each survey, we asked open-ended questions regarding what the participants liked about the training session and how we could improve. After each training session, the development team met for $45 \mathrm{~min}$ to discuss what went well and what could be improved, which were captured as notes to implement into the next iteration of the training program. A single, summative PCOR session for the CF community was provided by the researcher-clinician colead and a patient-partner as a podcast through CFRI in July, 2020 [31]. This podcast was not evaluated by our team.

\section{Data analysis}

The public health researcher performed the statistical analysis of the survey responses and created the data tables and figures. We conducted descriptive statistics for participant characteristics and median scores with inter quartile range (IQR) for post Training 1 (Research 101). For Trainings $2-4$, we calculated the median preand post-training score for each PCOR knowledge and confidence in engagement questions. We also assessed the difference between training attendees' self-rated preand post-training responses using the sign test. Because the sample size was small and not normally distributed, we used non-parametric summary statistics and tests. We used the sign test specifically to assess whether there was a significant directional change in the pre- and posttraining responses for individual responses $(\mathrm{alpha}=0.05)$ [32]. We performed statistical analysis using $R$ version 3.6.3 with RStudio version 1.3.1093 [33]. We summarized responses to open-ended questions after each training session regarding suggestions for improvement. The patient-partners provided input on how best to display the results with tables and figures.

\section{Results \\ Training program content}

Our pilot PCOR training program consisted of four separate core competencies: (1) Understand the principles of research; (2) Understand the science of PCOR; (3) Participate in and maintain a PCOR team; (4) Design and implement a PCOR study. Each core competency served as a separate session title and within each competency we listed learning objectives, training format, presenters/ facilitators and the learner group/audience for which the session was intended (see Appendix 2). Our first training was intended for patients/caregivers only (Research 101), and included a 25-min asynchronous, self-directed learning seminar intended to be viewed before the subsequent interactive PCOR sessions. The remaining three training programs were synchronous, interactive training sessions, lasting approximately $1.5 \mathrm{~h}$ each. Two of these sessions included both learner groups (patients/caregivers and researchers/providers) together (PCOR 101 and PCOR Team Dynamics) and one session (PCOR Study Design) was for researchers/healthcare providers only. The pilot training sessions can be downloaded here: familymedicine.uw.edu/pcor-guide/.

\section{Training program evaluation}

Training program participants included 28 patients and caregivers, and 31 researchers and providers. Several participants attended more than a single PCOR session. Detailed training program participant characteristics, including type of participant, job title, and attendees per session are reported in Table 1.

Overall, participants significantly improved selfassessed PCOR knowledge. The median Likert scale responses post-training for training session 1 and a test of the difference between knowledge perception questions administered before and after training sessions 2, 3, and 4 are presented in Table 2.

After Training 1 (Research 101), we found the majority of patients/caregivers reported being able to describe the different types of research methods $(15 / 17,88 \%)$, terminology $(14 / 17,82 \%)$, and modes of dissemination used in PCOR $(17 / 17,100 \%)$.

After Training 2 (PCOR 101), we found a significant difference in change of PCOR knowledge related to engagement levels compared to before among patients/caregivers and CF researchers/providers, ( $\mathrm{p}$ values $=0.008$ and 0.031 , respectively). Following the session, patients/caregivers reported being significantly 
Table 1 Training program participant characteristics

\begin{tabular}{ll}
\hline & N (\%) \\
\hline Total unique participants* $(n=59)$ & \\
Patients/caregivers & $28(48)$ \\
Researchers/providers & $31(53)$ \\
$\quad$ Clinic staff & $3(10)$ \\
$\quad$ Nurse & $3(10)$ \\
Physician/advanced practice provider & $8(26)$ \\
$\quad$ Researcher & $8(26)$ \\
Social worker & $3(10)$ \\
CF community organization & $4(13)$ \\
Student & $1(3)$ \\
$\quad$ Missing & $1(3)$ \\
Training 1: Research 101 ( $n=17)$ & \\
Patients/caregivers & $17(100)$ \\
Providers/researchers & $\mathrm{N} / \mathrm{A}$ \\
Training 2: PCOR 101 ( $n=26)$ & \\
Patients/caregivers & $15(58)$ \\
Providers/researchers & $11(42)$ \\
Training 3: PCOR team dynamics $(n=20)$ & \\
Patients/caregivers & $15(75)$ \\
Providers/researchers & $5(25)$ \\
Training 4: PCOR Study Design $(n=21)$ & \\
Patients/caregivers & N/A \\
Providers/researchers & $21(100)$ \\
\hline Some particpants atended &
\end{tabular}

* Some participants attended more than one training session

better able to identify barriers and enablers to adopting PCOR compared to pre-training $(p=0.016)$, whereas CF researchers/providers reported being significantly better able to describe and provide examples of the core principles of PCOR $(\mathrm{p}=0.017)$.

During Training 3 (PCOR Team Dynamics), patients/ caregivers significantly improved their PCOR knowledge in every aspect of the training except knowing how confidentiality of patient partners are maintained on PCOR teams. In contrast, we found no reported significant PCOR knowledge changes among CF researchers/providers. After this session, patients/caregivers reported being significantly better able to describe elements of an effective PCOR team $(\mathrm{p}=0.039)$, how to be an active participant throughout the research process $(p=0.012)$, how to identify barriers to successfully functioning PCOR teams $(\mathrm{p}=0.021)$.

In Training 4 (PCOR Study Design for CF Researchers/Providers only), participants reported significant improvement of their PCOR knowledge in every aspect of the training, including how to identify patients and caregivers to participate as partners in research, formulate research questions from patient-driven priorities, articulate successful components of an engagement plan in grant applications, and describe the patient partner role at every stage of the research project ( $\mathrm{p}$-values $=0.039,0.039,0.006,0.001$ ).

\section{Confidence with engaging partners in PCOR}

Confidence was only solicited in surveys related to Training 2-4. The median confidence score of patient/caregiver participants attending training sessions 2 (PCOR 101) or 3 (PCOR Team Dynamics) to engage as a partner in research was a "4" (fairly confident), which did not change significantly after either training. Similarly, the median confidence score of CF researchers/providers attending training sessions 2, 3 or 4 (PCOR Study Design) did not change significantly: self-rated confidence to engage $\mathrm{PwCF}$ in research before each training was either " 3 " (neutral) or "4" (fairly confident), and after each training was " 4 " (fairly confident).

\section{Training session satisfaction}

Overall, both learner groups were satisfied with the format of each training session (Fig. 3). The highest proportion of participants from either the patient or researcher/ provider group who reported being very satisfied with the training occurred with Training 3 (PCOR team dynamics) compared with the other training sessions.

\section{Training satisfaction: open-ended questions}

Training 1 (Research 101) The most common beneficial aspects participants noted was learning about research terminology, the grant submission process, how to design research questions, and the difference between types of research studies (e.g., quantitative vs qualitative and retrospective vs prospective). Most participants appreciated the inclusion of multiple speakers, including people with $\mathrm{CF}$ and the incorporation of visuals.

Training 2 (PCOR 101) Most participants liked the interaction between patients, caregivers, researchers and healthcare providers and the fact that the learners were taught together. Some participants reported not liking required participation in the interactive portions of the training, while others thought the breakout sessions were too small and too short. One person suggested having facilitators participate in each group to help move the conversation along.

Training 3 (PCOR Team Dynamics) This training included two case scenarios related to: (1) creating a respectful space for collective sharing, and (2) building and maintaining trust. Within each scenario, 
Table 2 Participant self-assessment of PCOR knowledge Likert scale responses pre- and post-training

\begin{tabular}{ll}
\hline $\begin{array}{l}\text { Training 1: research } 101 \\
\text { (patients/caregivers only) }\end{array}$ & Patient/ca \\
& Median \\
& Post only \\
\hline I can describe the different types of research methods used in PCOR & $4[4,4]$ \\
I can describe the processes, sections, and terminology of a research grant & $4[4,4]$ \\
I can describe the processes of disseminating study findings (e.g., publication, & $4[4,5]$
\end{tabular}

poster, oral presentation)

\begin{tabular}{|c|c|c|c|c|c|c|}
\hline \multirow[t]{3}{*}{$\begin{array}{l}\text { Training 2: PCOR } 101 \\
\text { (both learner groups) }\end{array}$} & \multicolumn{3}{|c|}{ Patient/caregiver $(n=15)$} & \multicolumn{3}{|c|}{$\begin{array}{l}\text { Researchers/ } \\
\text { providers }(n=11)\end{array}$} \\
\hline & \multicolumn{2}{|l|}{ Median response } & \multirow{2}{*}{$\begin{array}{l}\text { Difference } \\
\text { p value }\end{array}$} & \multicolumn{2}{|c|}{$\begin{array}{l}\text { Median } \\
\text { response }\end{array}$} & \multirow{2}{*}{$\begin{array}{l}\text { Difference } \\
\text { p value }\end{array}$} \\
\hline & Pre & Post & & Pre & Post & \\
\hline $\begin{array}{l}\text { I can identify the benefits and value of patient/caregiver engagement in } \\
\text { research }\end{array}$ & 4 & 5 & 0.13 & 4 & 5 & 0.13 \\
\hline I can define the levels of patient engagement, from minimal to control & 3 & 4 & 0.008 & 3.5 & 5 & 0.031 \\
\hline I can describe and provide examples of the core principles of PCOR & 3 & 4 & 0.11 & 3 & 5 & 0.016 \\
\hline $\begin{array}{l}\text { I can articulate how PCOR findings improve health in the community, raise } \\
\text { awareness, and increase patient advocacy }\end{array}$ & 4 & 4 & 1 & 4 & 5 & 0.063 \\
\hline $\begin{array}{l}\text { I can identify barriers to adopting PCOR and enablers to undertaking this } \\
\text { type of research }\end{array}$ & 4 & 4 & 0.017 & 4 & 5 & 0.13 \\
\hline $\begin{array}{l}\text { I can identify ways to turn PCOR work into academic productivity (HCP } \\
\text { only) }\end{array}$ & NA & NA & NA & 4 & 4 & 0.063 \\
\hline
\end{tabular}

\section{Training 3: PCOR team dynamics} (both learner groups)
Patient/caregiver $(n=17)$

Median response [IQR]

$[4,4]$

$[4,4]$

$[4,5]$

\begin{tabular}{|c|c|c|c|c|c|c|}
\hline & \multicolumn{2}{|l|}{ Median response } & \multirow{2}{*}{$\begin{array}{l}\text { Difference } \\
\text { p value }\end{array}$} & \multicolumn{2}{|c|}{$\begin{array}{l}\text { Median } \\
\text { response }\end{array}$} & \multirow{2}{*}{$\begin{array}{l}\text { Difference } \\
\text { p value }\end{array}$} \\
\hline & Pre & Post & & Pre & Post & \\
\hline I can describe the elements of an effective PCOR team & 3 & 4 & 0.039 & 2 & 5 & 0.25 \\
\hline $\begin{array}{l}\text { I can describe how to create conditions for patient/caregiver partners to be } \\
\text { active participants within a PCOR team at every step of the research process } \\
\text { (HCP only) }\end{array}$ & NA & NA & NA & 2 & 5 & 0.063 \\
\hline $\begin{array}{l}\text { I can describe how to be an active participant in a PCOR team in every step } \\
\text { of the process (pts only) }\end{array}$ & 2 & 4 & 0.012 & NA & NA & NA \\
\hline I can identify barriers to successfully functioning PCOR teams & 4 & 4 & 0.004 & 2 & 5 & 0.13 \\
\hline $\begin{array}{l}\text { I can articulate potential solutions to address barriers to successfully func- } \\
\text { tioning PCOR teams }\end{array}$ & 4 & 5 & 0.021 & 3 & 4 & 0.063 \\
\hline $\begin{array}{l}\text { I know how confidentiality of patient/caregiver partners will be maintained } \\
\text { on a PCOR team }\end{array}$ & 4 & 5 & 0.18 & 4 & 5 & 0.25 \\
\hline
\end{tabular}

\begin{tabular}{|c|c|c|c|}
\hline \multirow[t]{3}{*}{ Training 4: PCOR study design (researchers/providers only) } & \multicolumn{3}{|c|}{ Researchers/providers $(n=21)$} \\
\hline & \multicolumn{2}{|c|}{ Median response } & \multirow[t]{2}{*}{ Diff } \\
\hline & Pre & Post & \\
\hline $\begin{array}{l}\text { I know how to identify patients and caregivers to participate as partners in } \\
\text { research }\end{array}$ & 4 & 4 & 0.039 \\
\hline I know how to formulate research questions from patient-driven priorities & 4 & 4 & 0.039 \\
\hline $\begin{array}{l}\text { I can describe successful components of patient engaged research in a grant } \\
\text { application }\end{array}$ & 4 & 4 & 0.006 \\
\hline $\begin{array}{l}\text { I can articulate the role of patient and caregiver partners at every stage of the } \\
\text { research project }\end{array}$ & 3 & 4 & 0.001 \\
\hline
\end{tabular}

P values noting significant differences between pre- and post training are bolded. $(1=$ strongly disagree, $2=$ disagree, $3=$ neutral, $4=$ agree, $5=$ strongly agree) 


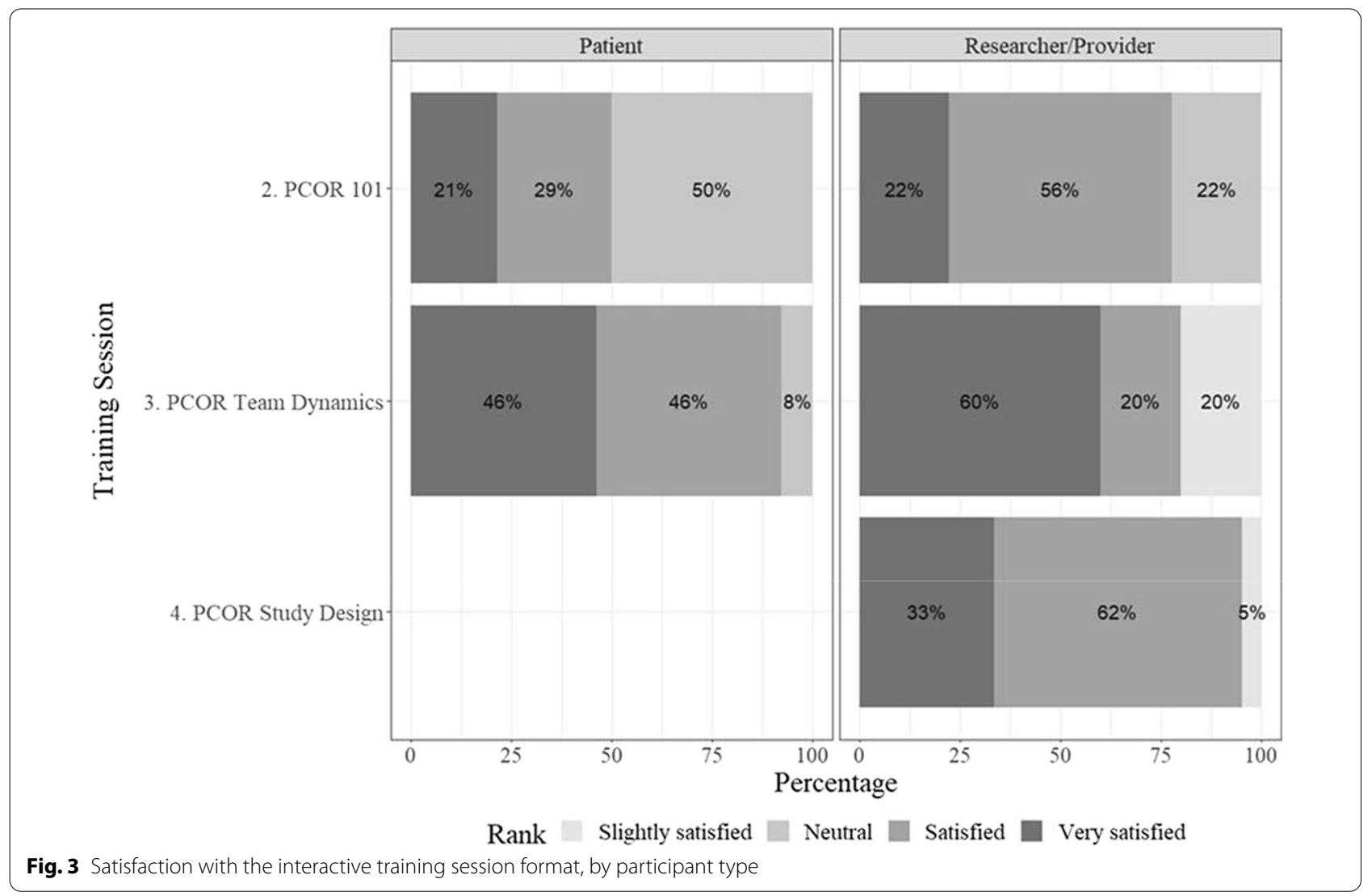

participants were asked to identify barriers to a successfully functioning PCOR team and articulate potential solutions to address those barriers. All participants commented that they enjoyed the discussion of both case scenarios, and thought they clearly illustrated potential challenges PCOR teams face. Participants also liked how facilitators engaged to advance the discussions. For example, one researcher/provider participant noted that all participants were "encouraged to speak". Participants suggested including more role playing for this training.

Training 4 (PCOR Study Design) Participants favorably rated the video conferencing format and thought the session was easy to join. Several suggestions for improvement included: Offering closed captioning versions of the presentation for viewing in different languages (including English for Deaf viewers); shorten the panel discussion and bring back the interactive breakout session format; provide more specific examples of how including patients or caregivers on the research team improves the quality and relevance of research; include example documents, such as a patient partner biographies and a list of potential patient partner roles; include more discussion of ways to include a diverse representation of patients on the research team.

\section{Discussion}

In this study, our team, consisting of researchers, clinicians, PwCF and CF advocates, developed and evaluated four unique virtual training sessions related to patient/ caregiver engagement on CF research teams. Based on the results of our prior educational needs assessment [14], we worked with an educational specialist to identify competencies and used an iterative process to specify our learning objectives based on the Model of Improvement [16]. We customized existing PCOR materials to meet the needs of the CF community, which called for incorporation of key adult learning principles, including pre-training materials, learning aids, and multi-modal learning strategies (e.g., didactics, small group activities, discussions, and question/answer sessions). Our findings suggest participants improved their knowledge about PCOR after each training session. Participants had fairly high confidence about their own PCOR skills at baseline, a measurement which did not significantly change with the PCOR training. Regardless of change in PCOR knowledge 
or confidence, participants in both learner groups (researchers/providers and patients/caregivers) were very satisfied with the teaching sessions. With high confidence and satisfaction, it is likely that learners who attended the sessions felt favorably about PCOR going into the sessions, but the change in baseline knowledge suggests that this filled a learning gap for the CF community.

This study is unique because of the level of engagement of our patient- and stakeholder-partners who maintained input into the project starting at the grant generation stage through dissemination of the findings. Our process of highlighting patient-partner skills (in addition to their insights as persons with the disease) allowed our patient-partners to more fully contribute to team activities. Additionally, open-ended comments from training participants indicated positive feedback in having PwCF and researchers teaching together. The input of the patient-partners helped make the didactic material more relatable to the audience. The impact of PPI in this work enabled our team's patient-partners to intimately learn about PCOR. As a result, they wrote and published an article about PCOR in a widely read quarterly periodical by CF patients [34] and produced an asynchronous podcast for the CF community that is publicly available [31].

As major funding agencies increasingly encourage and expect the inclusion of patient stakeholders on grant applications (i.e., by making such engagement a requirement for funding) [35], patient and caregiver partners will increasingly begin to join CF clinical research teams and accordingly, CF researchers will need adequate skills to successfully integrate these members. Engaging patients and caregivers for the long-term requires a sustained approach to support CF researchers and team collaborations, and to ensure PCOR principles of belonging and collaborative learning are actualized [20]. Other PCOR training programs such as one developed by the National Organization of Rare Disorders (NORD) in conjunction with the University of Maryland also contains the notion of sustaining support for PCOR by developing a pipeline of qualified and skilled mentors in PCOR methodology for new PCOR teams [23]. A separate study found that training priorities should include helping team members identify appropriate patient partners, devising an engagement strategy that clarifies roles and expectations, and building skills for positive team dynamics [36]. Prior training suggests that learning is not a singular one-time event, but comes from the act of "doing." Thus, ideally research teams should have an opportunity to participate in a PCOR mentoring program in which they can integrate patient/caregiver partners and have experts with whom to consult.
Our study had some limitations. Per the GRIPP2 guidelines, we did not quantitatively measure the impact of PPI in this study. We did, however, collect qualitative feedback about the impact of PPI from training participants, many of whom indicated positive comments about seeing PwCF as leaders of this work. Another limitation of this study was the low participation rates, which we believe was primarily due to our recruitment strategy. We had intended for the program to be presented sequentially with the same participants attending each training session. Thus, we initially limited our invitations to only those participants who had attended the prior session. We eventually opened our invitations to CF community members who had participated in our prior needs assessment, but finding a mutual time for synchronous training was difficult to achieve with busy work schedules. Our program evaluation was limited to feedback occurring immediately post-training. We did not include an evaluation process that assessed whether attendees later incorporated PCOR onto their research teams, or whether patients/ caregivers joined research teams after receiving the training.

\section{Conclusions}

A core team of researchers, patient-partners and advocacy stakeholders successfully co-developed four pilot PCOR training programs and a publicly available podcast about how to increase patient-engagement capacity on research teams. This CF-specific PCOR training was well received by patients, caregivers, health care providers and CF researchers. The program significantly improved PCOR knowledge with core PCOR learning items. The training development team is now creating a new, comprehensive PCOR training manual with input from stakeholders from the CF community, with the goal of increasing interest in PCOR skills and methods among CF clinical researchers.

\section{Appendix 1: PCOR training-adapted materials}

Our team conducted an online search for existing PCOR training materials. Identified materials were mapped to specific competencies and adapted for our specific training goals, core competencies and learning objectives. A summary of the materials adapted for use in our training is provided below. 


\begin{tabular}{|c|c|c|c|c|c|}
\hline Teaching concept & Training theme & $\begin{array}{l}\text { Pre-existing resource } \\
\text { identified }\end{array}$ & Teaching concept & Training theme & $\begin{array}{l}\text { Pre-existing resource } \\
\text { identified }\end{array}$ \\
\hline \multicolumn{3}{|c|}{ Why engage patients and caregivers in research? } & \multirow{2}{*}{$\begin{array}{l}\text { True partner engage- } \\
\text { ment }\end{array}$} & \multirow{3}{*}{$\begin{array}{l}\text { Defining partnerships } \\
\text { and engagement in } \\
\text { research } \\
\text { Principles of authentic } \\
\text { partnerships } \\
\text { Strengths and weak- } \\
\text { nesses of full patient } \\
\text { engagement in } \\
\text { research } \\
\text { Time and resources } \\
\text { needed for patient- } \\
\text { engaged research } \\
\text { How to evaluate } \\
\text { partnerships }\end{array}$} & \multirow{3}{*}{$\begin{array}{l}\text { http://trailhead.insti } \\
\text { tute/wp-content/uploa } \\
\text { ds/2017/04/truepatien } \\
\text { tpartnerengagement_- } \\
\text { final.pdf }\end{array}$} \\
\hline $\begin{array}{l}\text { Better research through } \\
\text { engagement }\end{array}$ & $\begin{array}{l}\text { How engagement } \\
\text { helps us do our work } \\
\text { Why engagement } \\
\text { matters } \\
\text { Patient and stake- } \\
\text { holder involvement } \\
\text { Strengthening the } \\
\text { PCOR community } \\
\text { Advancing engage- } \\
\text { ment \& influencing } \\
\text { others }\end{array}$ & $\begin{array}{l}\text { https://www.pcori. } \\
\text { org/sites/default/files/ } \\
\text { PCORI-Better-Resea } \\
\text { rch-Through-Engag } \\
\text { ement.pdf }\end{array}$ & & & \\
\hline \multirow{2}{*}{$\begin{array}{l}\text { Research done differ- } \\
\text { ently }\end{array}$} & \multirow[b]{2}{*}{$\begin{array}{l}\text { What is PCOR } \\
\text { What do we mean by } \\
\text { patient-centered } \\
\text { PCORI funding for } \\
\text { patient-centered } \\
\text { studies } \\
\text { Testimonials }\end{array}$} & \multirow{2}{*}{$\begin{array}{l}\text { https://www.pcori. } \\
\text { org/sites/default/files/ } \\
\text { PCORI-Research-Done- } \\
\text { Differently.pdf }\end{array}$} & & & \\
\hline & & & \multirow[t]{2}{*}{$\begin{array}{l}\text { Roles of patient and } \\
\text { caregiver partners in } \\
\text { research }\end{array}$} & \multirow{2}{*}{$\begin{array}{l}\text { Common patient- } \\
\text { partner activities and } \\
\text { effects of partner } \\
\text { engagement } \\
\text { Examples of effects of } \\
\text { partner engagement } \\
\text { in planning, conduct- } \\
\text { ing, and disseminat- } \\
\text { ing phases of a study }\end{array}$} & \multirow[t]{2}{*}{$\begin{array}{l}\text { https://www.pcori. } \\
\text { org/sites/default/files/ } \\
\text { PCORI-Engagement- } \\
\text { in-Research-Making- } \\
\text { a-Difference-Webinar- } \\
\text { Info-Sheet-091917.pdf }\end{array}$} \\
\hline \multirow[t]{2}{*}{$\begin{array}{l}\text { Impact of engagement } \\
\text { in research }\end{array}$} & \multirow{2}{*}{$\begin{array}{l}\text { Evaluation framework } \\
\text { for assessing short- } \\
\text { and long-term impact } \\
\text { of engagement } \\
\text { What PCORI considers } \\
\text { engagement } \\
\text { Effect of engagement } \\
\text { on study design, pro- } \\
\text { cesses, and outcomes } \\
\text { selection }\end{array}$} & \multirow{2}{*}{$\begin{array}{l}\text { Forsythe, L., Heckert, A., } \\
\text { Margolis, M.K. et al. Qual } \\
\text { Life Res (2018) 27: } 17 . \\
\text { https://doi.org/10.1007/ } \\
\text { s11136-017-1581-x }\end{array}$} & & & \\
\hline & & & \multirow[t]{5}{*}{$\begin{array}{l}\text { Initiative to support } \\
\text { patient involvement } \\
\text { in research (INSPIRE): } \\
\text { community workshop } \\
\text { report }\end{array}$} & \multirow{5}{*}{$\begin{array}{l}\text { Describes how to } \\
\text { build infrastructure for } \\
\text { patient engagement } \\
\text { Discusses mentor- } \\
\text { ship and training to } \\
\text { develop meaningful } \\
\text { patient engagement } \\
\text { and roles for patient- } \\
\text { partners in research } \\
\text { Discusses different } \\
\text { models of engage- } \\
\text { ment (i.e., engage- } \\
\text { ment as part of a } \\
\text { research study vs. } \\
\text { as part of research } \\
\text { institution) } \\
\text { Provides recommen- } \\
\text { dations for future } \\
\text { patient engagement } \\
\text { (e.g., peer-to-peer } \\
\text { mentoring program } \\
\text { for researchers and } \\
\text { patients, research } \\
\text { orientation) and for } \\
\text { increasing diversity } \\
\text { in patient-researcher } \\
\text { partnerships }\end{array}$} & \multirow{5}{*}{$\begin{array}{l}\text { Lavalle DC, Gore JL, } \\
\text { Lawrence SO, Lindsay } \\
\text { J, Marsh S, Scott MR, } \\
\text { Wernli K. Initiative to } \\
\text { Support Patient Involve- } \\
\text { ment in Research } \\
\text { (INSPIRE): Community } \\
\text { Workshop Report [Inter- } \\
\text { net]. October 2016. } \\
\text { Available from: https:// } \\
\text { www.becertain.org/ } \\
\text { sites/default/files/INSPI } \\
\text { RE\%20PCOR\%20Wor } \\
\text { kshop\%20Summary\% } \\
\text { 20FINAL\%202016.10. } \\
\text { 05.pdf }\end{array}$} \\
\hline \multicolumn{3}{|c|}{ How to engage patients and caregivers as partners in research } & & & \\
\hline Research fundamentals & $\begin{array}{l}\text { Comprehensive train- } \\
\text { ing package to learn } \\
\text { about the research } \\
\text { process and to be } \\
\text { involved in PCOR }\end{array}$ & $\begin{array}{l}\text { https://www.pcori.org/ } \\
\text { engagement/research- } \\
\text { fundamentals }\end{array}$ & & & \\
\hline $\begin{array}{l}\text { Initiating partnerships } \\
\text { for } P C O R\end{array}$ & $\begin{array}{l}\text { How researchers } \\
\text { can engage patients } \\
\text { and stakeholders } \\
\text { to improve patient- } \\
\text { centered research } \\
\text { Where to find poten- } \\
\text { tial research partners } \\
\text { Lessons learned about } \\
\text { initiating research } \\
\text { partnerships }\end{array}$ & $\begin{array}{l}\text { https://www.pcori. } \\
\text { org/sites/default/files/ } \\
\text { PCORI-Engagement- } \\
\text { Strategies-for-Initiating- } \\
\text { Research-Partnershi } \\
\text { ps-Info-Sheet-71917.pdf }\end{array}$ & & & \\
\hline \multirow[t]{2}{*}{$\begin{array}{l}\text { Developing research } \\
\text { partnerships }\end{array}$} & \multirow{2}{*}{$\begin{array}{l}\text { Forming partnerships } \\
\text { with patients and } \\
\text { other stakeholders } \\
\text { Where and how to } \\
\text { find partners } \\
\text { Considerations in } \\
\text { clinician partnerships } \\
\text { Lessons learned } \\
\text { from PCORI funded } \\
\text { research teams }\end{array}$} & \multirow{2}{*}{$\begin{array}{l}\text { Anyanwu C, Hemphill R. } \\
\text { Finding and Recruit- } \\
\text { ing Research Partners: } \\
\text { Lessons from PCORI } \\
\text { Awardees. PCORI } \\
\text { Engagement Blogs. Sep } \\
\text { 1, 2017. https://www. } \\
\text { pcori.org/blog/findi } \\
\text { ng-and-recruiting-resea } \\
\text { rch-partners-lessons- } \\
\text { pcori-awardees }\end{array}$} & & & \\
\hline & & & $\begin{array}{l}\text { Stakeholder engage- } \\
\text { ment challenges, strat- } \\
\text { egies, and resources }\end{array}$ & $\begin{array}{l}\text { Common challenges } \\
\text { of partner engage- } \\
\text { ment in research } \\
\text { Strategies to prevent } \\
\text { or address challenges } \\
\text { to engaged research } \\
\text { PCORl engagement } \\
\text { resources }\end{array}$ & $\begin{array}{l}\text { https://www.pcori. } \\
\text { org/sites/default/files/ } \\
\text { PCORI-Patient-Stake } \\
\text { holder-Engagement- } \\
\text { Challenges-Strat } \\
\text { egies-Resources-Hando } \\
\text { ut-120517.pdf }\end{array}$ \\
\hline
\end{tabular}




\begin{tabular}{|c|c|c|}
\hline Teaching concept & Training theme & $\begin{array}{l}\text { Pre-existing resource } \\
\text { identified }\end{array}$ \\
\hline \multicolumn{3}{|c|}{ How to include PCOR in grant applications } \\
\hline $\begin{array}{l}\text { PCORlengagement } \\
\text { plan template }\end{array}$ & $\begin{array}{l}\text { Helps study teams } \\
\text { refine engagement } \\
\text { plan } \\
\text { Guides research team } \\
\text { to fulfill the objec- } \\
\text { tives of patient- and } \\
\text { stakeholder-engaged } \\
\text { research }\end{array}$ & $\begin{array}{l}\text { https://www.pcori. } \\
\text { org/sites/default/files/ } \\
\text { PCORI-Updated-Engag } \\
\text { ement-Plan-Template. } \\
\text { pdf }\end{array}$ \\
\hline $\begin{array}{l}\text { PCORI engagement } \\
\text { rubric for applicants }\end{array}$ & $\begin{array}{l}\text { How input from } \\
\text { patient and stake- } \\
\text { holder partners can } \\
\text { be used throughout } \\
\text { the research process } \\
\text { Provides PCORI } \\
\text { engagement princi- } \\
\text { ples, definitions, and } \\
\text { key considerations for } \\
\text { planning, conducting, } \\
\text { and disseminating } \\
\text { patient-engaged } \\
\text { research } \\
\text { Provides specific } \\
\text { examples of potential } \\
\text { partner activities } \\
\text { for each part of the } \\
\text { PCORI grant applica- } \\
\text { tion }\end{array}$ & $\begin{array}{l}\text { PCORI Engagement } \\
\text { Rubric. PCORI (Patient- } \\
\text { Centered Outcomes } \\
\text { Research Institute) } \\
\text { website } \\
\text { https://www.pcori. } \\
\text { org/sites/default/files/ } \\
\text { Engagement-Rubric.pdf } \\
\text { Published February 4, } \\
\text { 2014. Updated October } \\
\text { 12,2015. Accessed } \\
\text { 1/20/2020 }\end{array}$ \\
\hline $\begin{array}{l}\text { PCORI compensation } \\
\text { framework }\end{array}$ & $\begin{array}{l}\text { Guidelines for } \\
\text { compensating } \\
\text { patients, caregivers, } \\
\text { and organizations } \\
\text { engaged in PCORI } \\
\text { funded research as } \\
\text { research partners } \\
\text { Provides varying com- } \\
\text { pensation levels for } \\
\text { level of engagement }\end{array}$ & $\begin{array}{l}\text { https://www.pcori. } \\
\text { org/sites/default/files/ } \\
\text { PCORI-Compensation- } \\
\text { Framework-for-Engag } \\
\text { ed-Research-Partners. } \\
\text { pdf }\end{array}$ \\
\hline $\begin{array}{l}\text { Budget for engage- } \\
\text { ment activities }\end{array}$ & $\begin{array}{l}\text { Considerations for: } \\
\text { Compensation and } \\
\text { recognition } \\
\text { Patient and caregiver } \\
\text { partner expenses } \\
\text { Project staff } \\
\text { Engagement event } \\
\text { costs } \\
\text { Incorporating partner } \\
\text { feedback }\end{array}$ & $\begin{array}{l}\text { https://www.pcori. } \\
\text { org/sites/default/files/ } \\
\text { PCORI-Budgeting-for- } \\
\text { Engagement-Activ } \\
\text { ities.pdf }\end{array}$ \\
\hline $\begin{array}{l}\text { PCOR and IRB points to } \\
\text { consider }\end{array}$ & $\begin{array}{l}\text { Planning considera- } \\
\text { tions } \\
\text { Issues for IRB submis- } \\
\text { sions and reviews } \\
\text { (e.g., standard care vs. } \\
\text { research interven- } \\
\text { tions, advertisements, } \\
\text { informed consent, } \\
\text { HIPAA...) }\end{array}$ & $\begin{array}{l}\text { https://www.partners. } \\
\text { org/Assets/Documents/ } \\
\text { Medical-Research/Clini } \\
\text { cal-Research/PCOR- } \\
\text { and-IRB-Points-to-Consi } \\
\text { der.pdf }\end{array}$ \\
\hline
\end{tabular}

\begin{tabular}{|c|c|c|}
\hline Teaching concept & Training theme & $\begin{array}{l}\text { Pre-existing resource } \\
\text { identified }\end{array}$ \\
\hline \multicolumn{3}{|l|}{$\overline{\text { PCOR } 101}$} \\
\hline $\begin{array}{l}\text { Traditional research vs. } \\
\text { community-engaged } \\
\text { research }\end{array}$ & $\begin{array}{l}\text { Explains the dif- } \\
\text { ference between } \\
\text { traditional and } \\
\text { community-engaged } \\
\text { research and provides } \\
\text { examples of both } \\
\text { Community-engaged } \\
\text { research questions } \\
\text { Challenges to } \\
\text { community-engaged } \\
\text { research and how } \\
\text { to overcome these } \\
\text { barriers }\end{array}$ & $\begin{array}{l}\text { http://trailhead.insti } \\
\text { tute/wp-content/uploa } \\
\text { ds/2017/04/316043919- } \\
\text { community-engaged- } \\
\text { research-final.pdf }\end{array}$ \\
\hline
\end{tabular}

PCOR team dynamics

Team science SWOG field guide

Collaboration and team science

TeamSTEPPS 


\begin{tabular}{|c|c|c|}
\hline Teaching concept & Training theme & $\begin{array}{l}\text { Pre-existing resource } \\
\text { identified }\end{array}$ \\
\hline \multicolumn{3}{|l|}{ Online collaboration } \\
\hline $\begin{array}{l}\text { Overcoming chal- } \\
\text { lenges in collaborating } \\
\text { online }\end{array}$ & $\begin{array}{l}\text { Solutions for the fol- } \\
\text { lowing challenges: } \\
\text { Communication } \\
\text { Establishing and } \\
\text { maintaining trust } \\
\text { Productivity } \\
\text { Lessons learned: } \\
\text { Adjust for size of } \\
\text { projects } \\
\text { Don't be afraid of } \\
\text { social media } \\
\text { Play games } \\
\text { Train for collaboration } \\
\text { Have role clarity but } \\
\text { task uncertainty }\end{array}$ & $\begin{array}{l}\text { Challenges to Manag- } \\
\text { ing Virtual Teams and } \\
\text { How to Overcome } \\
\text { Them. Harvard Division } \\
\text { of Continuing Educa- } \\
\text { tion. Blog. https://www. } \\
\text { extension.harvard. } \\
\text { edu/professional-devel } \\
\text { opment/blog/chall } \\
\text { enges-managing-virtu } \\
\text { al-teams-and-how- } \\
\text { overcome-them } \\
\text { Ferrazzi K. How Suc- } \\
\text { cessful Virtual Teams } \\
\text { Collaborate. Harvard } \\
\text { Business Review. 2012 } \\
\text { Oct. https://hbr.org/ } \\
\text { 2012/10/how-to-colla } \\
\text { borate-in-a-virtua }\end{array}$ \\
\hline
\end{tabular}

\section{Evaluating partnerships}

\begin{tabular}{|c|c|c|}
\hline $\begin{array}{l}\text { Measuring trust in } \\
\text { partnerships }\end{array}$ & $\begin{array}{l}\text { Identifies how trust } \\
\text { is conceptualized in } \\
\text { health promotion } \\
\text { partnerships } \\
\text { Provides a 14-item } \\
\text { trust measurement } \\
\text { tool }\end{array}$ & $\begin{array}{l}\text { Jones J, Barry MM. } \\
\text { Developing a scale to } \\
\text { measure trust in health } \\
\text { promotion partner- } \\
\text { ships. Health Promotion } \\
\text { International. } 2011 \\
\text { Feb;26(4):484-491. } \\
\text { http://trailhead.insti } \\
\text { tute/wp-content/uploa } \\
\text { ds/2017/04/health_- } \\
\text { promot_int_-2011- } \\
\text { jones-484-91.pdf }\end{array}$ \\
\hline
\end{tabular}

\section{PCOR in the literature}

CFexample

Health affairs
Kazmerski T.M., Miller E, Sawicki GS, Thomas P, Prushinskaya O, Nelson E, Hill K, Miller A, Emans SJ. Developing Sexual and Reproductive Health Educational Resources for Young Women with Cystic Fibrosis: A Structured Approach to Stakeholder Engagement. Patient. 2019 Apr;12(2):267-276 https://www.ncbi.nlm.nih.gov/pubmed/30361 885

Forsythe LP, Carman KL, Szydlowski V, Fayish L, Davidson L, Hickam DH, Hall C, Bhat G, Neu D, Stewart L, Jalowsky M, Aronson N, Anyanwu CU. Patient Engagement in Research: Early Findings From The Patient-Centered Outcomes Research Institute. Health Aff. 2019 Mar;38(3):359-36

https://www.healthaffairs.org/doi/full/10. 1377/hlthaff.2018.05067

\begin{tabular}{|c|c|c|}
\hline Teaching concept & Training theme & $\begin{array}{l}\text { Pre-existing resource } \\
\text { identified }\end{array}$ \\
\hline Health expectations & \multicolumn{2}{|c|}{$\begin{array}{l}\text { Shippee ND, Domecq Garces JP, Prutsky Lopez } \\
\text { GJ, Wang Z, Elraiyah TA, Nabhan M, Brito JP, } \\
\text { Boehmer K, Hasan R, Firwana B, Erwin PJ, Mon- } \\
\text { tori VM, Murad MH. Patient and service user } \\
\text { engagement in research: a systematic review } \\
\text { and synthesized framework. Health Expect. } \\
\text { 2015 Oct;18(5):1151-66. https://doi.org/10. } \\
\text { 1111/hex.12090. https://www.ncbi.nlm.nih. } \\
\text { gov/pmc/articles/PMC5060820/ } \\
\text { This paper uses a systematic review and } \\
\text { environmental scan to create an evidence- } \\
\text { based framework for patient and services user } \\
\text { engagement } \\
\text { The framework provides a standard structure } \\
\text { and language for reporting and indexing } \\
\text { to support comparative effectiveness and } \\
\text { optimize PCOR } \\
\text { Integral components include: reciprocal } \\
\text { relationships, colearning, re-assessment, and } \\
\text { feedback } \\
\text { The framework describes patient engage- } \\
\text { ment at several stages of research: prepara- } \\
\text { tory, execution, and translational }\end{array}$} \\
\hline BioMed Central & \multicolumn{2}{|c|}{$\begin{array}{l}\text { Staley K. 'Is it worth doing?' Measuring the } \\
\text { impact of patient and public involvement } \\
\text { in research. BMC Research Involvement and } \\
\text { Engagement. 2015;1(6). https://researchin } \\
\text { volvement.biomedcentral.com/articles/10. } \\
1186 / s 40900-015-0008-5 \\
\text { Discusses the current debate around the } \\
\text { impact of involving patients/community } \\
\text { members in research } \\
\text { Provides experiences from researchers engag- } \\
\text { ing in PCOR }\end{array}$} \\
\hline $\begin{array}{l}\text { Implementation } \\
\text { science }\end{array}$ & \multicolumn{2}{|c|}{$\begin{array}{l}\text { Bombard Y, Baker GR, Orlando E, et al. Engag- } \\
\text { ing patients to improve quality of care: a } \\
\text { systematic review. Implement Sci. 2018;13: } \\
98 \text {. https://link.springer.com/article/10.1186/ } \\
\text { s13012-018-0784-z } \\
\text { Systematic review from } 1990 \text { to } 2016 \text { for } \\
\text { empirical studies that address active participa- } \\
\text { tion of patients, caregivers, or families in the } \\
\text { design, delivery and evaluation of health } \\
\text { services to improve quality of care } \\
\text { Identifies strategies and contextual factors } \\
\text { that enable engagement of patients in the } \\
\text { design, delivery, and evaluation of health } \\
\text { services }\end{array}$} \\
\hline
\end{tabular}




\section{Appendix 2: CF community PCOR training core competencies, learning objectives, training format, presenters and learner groups}

At the end of the training program, participants should be able to:

\begin{tabular}{llll}
\hline $\begin{array}{l}\text { Learning } \\
\text { objectives }\end{array}$ & Training format & $\begin{array}{l}\text { Presenters/ } \\
\text { facilitators }\end{array}$ & $\begin{array}{l}\text { Learner group(s)/ } \\
\text { audience }\end{array}$
\end{tabular}

Competency 1: understand the principles of research (research 101)

Asynchronous

Didactics pre-

sented by two

types of research

methods used in

PCOR

self-directed

CF researchers

and three patien

-To describe

Time allotted:

partners with CF

the processes,

sections and

terminology of a

research grant

-To describe the

processes of

disseminating

study findings

(e.g., publica-

tion, poster, oral

presentation)

Competency 2: understand the science of PCOR (PCOR 101)

benefits and

value of patient

engagement in

research

Synchronous

Interactive

session

Time allotted:

90 min

-To define the

Activities:

levels of patient

engagement,

Didactics

from minimal

Small group

discussions

engagement to

control

-To describe

and provide

examples of the

core principles of

PCOR

-To articulate

how PCOR

findings improve

health in the

community, raise

awareness, and

increase patient

advocacy

-To understand

how to turn

PCOR work

into academic

productivity

-To identify

barriers to

adopting PCOR

and enablers to

undertaking this

type of research

Competency 3: participate in and maintain a PCOR team (PCOR team dynamics)
At the end of the training program, participants should be able to:

\begin{tabular}{|c|c|c|c|}
\hline $\begin{array}{l}\text { Learning } \\
\text { objectives }\end{array}$ & Training format & $\begin{array}{l}\text { Presenters/ } \\
\text { facilitators }\end{array}$ & $\begin{array}{l}\text { Learner group(s)/ } \\
\text { audience }\end{array}$ \\
\hline $\begin{array}{l}\text {-To describe } \\
\text { elements for } \\
\text { successful PCOR } \\
\text { team dynamics } \\
\text {-To describe } \\
\text { how to create } \\
\text { conditions for } \\
\text { patient-partners } \\
\text { to be active par- } \\
\text { ticipants within } \\
\text { a PCOR team at } \\
\text { every step of the } \\
\text { research process } \\
\text {-To identify bar- } \\
\text { riers to success- } \\
\text { fully functioning } \\
\text { PCOR teams and } \\
\text { articulate poten- } \\
\text { tial solutions to } \\
\text { address those } \\
\text { barriers } \\
\text {-To review strate- } \\
\text { gies to maintain } \\
\text { confidentiality of } \\
\text { patient-partners } \\
\text { when part of the }\end{array}$ & $\begin{array}{l}\text { Synchronous } \\
\text { Interactive } \\
\text { session } \\
\text { Time allotted: } \\
90 \text { min } \\
\text { Activities: } \\
\text { Didactics } \\
\text { Small group } \\
\text { case-based } \\
\text { discussions }\end{array}$ & $\begin{array}{l}\text { Opening com- } \\
\text { ments by a } \\
\text { health services } \\
\text { research gradu- } \\
\text { ate student } \\
\text { Didactics by one } \\
\text { CF researcher, } \\
\text { three patient } \\
\text { partners with CF, } \\
\text { and a CF stake- } \\
\text { holder organiza- } \\
\text { tion partner } \\
115 \text {-min small } \\
\text { group discussion } \\
\text { of two case } \\
\text { scenarios facili- } \\
\text { tated by one CF } \\
\text { researcher and } \\
\text { three patient } \\
\text { partners with CF } \\
1 \text { 8-min large } \\
\text { group discussion } \\
\text { facilitated by one } \\
\text { CF researcher } \\
\text { and three patient } \\
\text { partners with CF }\end{array}$ & $\begin{array}{l}\text { Patients/caregivers } \\
\text { Researchers/ } \\
\text { healthcare provid- } \\
\text { ers }\end{array}$ \\
\hline
\end{tabular}

research team

Competency 4: design and implement a PCOR study (PCOR study design)

-To articulate Synchronous Opening com- Researchers/

strategiesfor Interactive ments by a healthcare provid-

identifying session health services ers

patient and Time allotted: research gradu-

caregivers to $90 \mathrm{~min}$ ate student

participate Activities: Didactics by one

as partners in Didactics CF researcher

research Short panel pres- and two patient

-To formu- entation partners with CF

late research Q\&A session Panel discussion

questions from by two guest

patient-driven lecturers (one

priorities

-To identify

successful

components of

patient-engaged

healthcare

provider and

one caregiver

partner)

research in a

research grant

application

-To articulate the

role of patient-

partners at every

stage of the

research project

from research

question

development to

the grant writing

process to study

roll-out 


\section{Abbreviations}

CF: Cystic fibrosis; CFF: Cystic Fibrosis Foundation; CFReSHC: Cystic Fibrosis Reproductive and Sexual Health Collaborative; CFRI: Cystic Fibrosis Research Inc; IQR: Interquartile range; PCOR: Patient-centered outcomes research; PwCF: People with cystic fibrosis; NORD: National Organization of Rare Disorders.

\section{Acknowledgements}

The authors are grateful for the vital contributions from the participants of this training program and to our key stakeholders, the Cystic Fibrosis Foundation (CFF), CFRI, Inc and CFReSHC for their support of this work. We also thank Larry Kessler, ScD for his critical review of the manuscript.

\section{Authors' contributions}

EMG wrote the first draft and edited all subsequent drafts. EKT performed the data analysis. LM, TMK, GB, MP and MAA all reviewed and edited the manuscript.

\section{Funding}

This work was funded through the Patient-Centered Outcomes Research Institute (PCORI) Eugene Washington Program Award (10569-UWASH) and the National Center for Advancing Translational Sciences of the National Institutes of Health $(\mathrm{NIH})$ under Award Number UL1 TR002319. The content is solely the responsibility of the authors and does not necessarily represent the official views of PCORI or the $\mathrm{NIH}$

\section{Availability of data and materials}

The authors confirm that trainings, data collection tools are available within the article [and/or] supplementary materials. The datasets for the current study are not publicly available, but will be made available from the corresponding author on reasonable request.

\section{Declarations}

\section{Ethic approval and consent to participate}

The Human Subjects Review Board of the University of Washington (UW) approved this study (ID: STUDY00006146). All study requirements and procedures were explained to potential participants, and each participant provided informed consent.

\section{Consent for publication}

Not applicable.

\section{Competing interests}

Dr. Emily M. Godfrey is a Nexplanon trainer for Merck, outside the submitted work. The other authors declare that they have no competing interests.

\section{Author details}

'Department of Family Medicine, School of Medicine, University of Washington, 4311 11th Ave NE, Box 354982, Seattle, WA 98105, USA. ${ }^{2}$ Cystic Fibrosis Reproductive and Sexual Health Collaborative, Seattle, USA. ${ }^{3}$ Department of Pediatrics, School of Medicine, University of Pittsburgh, Pittsburgh, PA, USA.

Received: 23 August 2021 Accepted: 15 November 2021

Published online: 04 December 2021

\section{References}

1. Cystic Fibrosis Foundation Patient Registry 2019 Annual Data Report. Bethesda: Cystic Fibrosis Foundation; 2020.

2. Cystic Fibrosis Foundation. Community voice brings your voice into everything that we do. Bethesda: Cystic Fibrosis Foundation; 2017 [Descrption of Community Voice]. https://www.cff.org/CF-Commu nity-Blog/Posts/2017/Community-Voice-Brings-Your-Voice-Into-Every thing-That-We-Do/.

3. Cystic Fibrosis Research Inc. Research for living partners for life 2018. http://www.cfri.org/home.shtml.

4. Kwon SC, Tandon SD, Islam N, Riley L, Trinh-Shevrin C. Applying a community-based participatory research framework to patient and family engagement in the development of patient-centered outcomes research and practice. Transl Behav Med. 2018;8(5):683-91.

5. Saiman L, Siegel J. Infection control recommendations for patients with cystic fibrosis: microbiology, important pathogens, and infection control practices to prevent patient-to-patient transmission. Infect Control Hosp Epidemiol. 2003;24(5 Suppl):S6-52

6. Largent EA, Weissman JS, Gupta A, Abraham M, Rozenblum R, Lynch HF, et al. Patient-centered outcomes research: stakeholder perspectives and ethical and regulatory oversight issues. IRB. 2018:40(1):7-17.

7. Concannon TW, Fuster M, Saunders T, Patel K, Wong JB, Leslie LK, et al. A systematic review of stakeholder engagement in comparative effectiveness and patient-centered outcomes research. J Gen Intern Med. 2014;29(12):1692-701.

8. Forsythe LP, Frank LB, Workman TA, Borsky A, Hilliard T, Harwell D, et al. Health researcher views on comparative effectiveness research and research engagement. J Comp Eff Res. 2017;6(3):245-56.

9. Hughes P, Grace B. Gracious Space: Working Together Better. CEL Publications; 2010

10. Gafni A, Charles C. The physician-patient encounter: an agency relationship. Shared decision-making in health care achieving evidence-based patient choice. New York: Oxford University Press; 2009. p. 73-8.

11. Jimenez XF. Attachment in medical care: a review of the interpersonal model in chronic disease management. Chronic IIIn. 2017;13(1):14-27.

12. Sacristán JA, Aguarón A, Avendaño-Solá C, Garrido P, Carrión J, Gutiérrez $A$, et al. Patient involvement in clinical research: why, when, and how. Patient Prefer Adher. 2016;10:631-40.

13. Sufian S, Mentch L, Godfrey EM. Women with CF are helping guide reproductive and sexual health research. CF Roundtable. 2017:40.

14. Godfrey EM, Kazmerski TM, Brown G, Thayer EK, Mentch L, Pam M, et al. Educational needs and preferences for patient-centered outcomes research in the cystic fibrosis community: mixed methods study. JMIR Form Res. 2021;5(3):e24302.

15. Staniszewska S, Brett J, Simera I, Seers K, Mockford C, Goodlad S, et al. GRIPP2 reporting checklists: tools to improve reporting of patient and public involvement in research. Research Involv Engagem. 2017:3(1):13.

16. Langley GJ. The improvement guide: a practical approach to enhancing organizational performance, 2nd ed. In: Langley GJ, editor. San Francisco: Jossey-Bass; 2009.

17. Long-Genovese S. A guide to best practices in training development. In: Institute of Translational Health Sciences, editor. Seattle, WA: University of Washington; 2017.

18. Anderson LW, Krathwohl DR. A taxonomy for learning, teaching, and assessing: a revision of Bloom's taxonomy of educational objectives. Complete. New York: Longman; 2001.

19. Ambrose SA, Bridges MW, DiPietro M, Lovett MC, Norman MK, Mayer RE. How learning works: seven research-based principles for smart teaching. Hoboken: Wiley; 2010.

20. Silberman ML, Biech E, Auerbach C. Active training: a handbook of techniques, designs, case examples, and tips. New York: Wiley; 2015.

21. Adams A, Williamson A, Sorkness C, Hatfield P, Eggen A, Esmond S. The steps model: a practical tool for engaging communities to improve health outcomes. Acad Med J Assoc Am Med Coll. 2017;92(6):890.

22. Anyanwu CU, Hemphill R. PCORI engagement blogs. Washington, DC: PCORI. 2017. https://www.pcori.org/blog/finding-and-recruiting-resea rch-partners-lessons-pcori-awardees.

23. Bennett LM, Gadlin H. Collaboration and team science: from theory to practice. J Investig Med. 2012;60(5):768-75.

24. Forsythe L, Heckert A, Margolis MK, Schrandt S, Frank L. Methods and impact of engagement in research, from theory to practice and back again: early findings from the Patient-Centered Outcomes Research Institute. Qual Life Res. 2018;27(1):17-31.

25. Forsythe LP, Carman KL, Szydlowski V, Fayish L, Davidson L, Hickam $\mathrm{DH}$, et al. Patient engagement in research: early findings from the patient-centered outcomes research institute. Health Aff (Millwood). 2019;38(3):359-67.

26. Jones J, Barry MM. Developing a scale to measure trust in health promotion partnerships. Health Promot Int. 2011;26(4):484-91.

27. Kazmerski TM, Miller E, Sawicki GS, Thomas P, Prushinskaya O, Nelson E, et al. Developing sexual and reproductive health educational resources for young women with cystic fibrosis: a structured approach to stakeholder engagement. Patient. 2019;12(2):267-76. 
28. Minneci PC, Nacion KM, Lodwick DL, Cooper JN, Deans KJ. Improving surgical research by involving stakeholders. JAMA Surg. 2016;151(6):579-80.

29. Sheridan S, Schrandt S, Forsythe L, Hilliard TS, Paez KA. The PCORI engagement rubric: promising practices for partnering in research. Ann Fam Med. 2017;15(2):165-70.

30. Thayer EK, Pam M, Al Achkar M, Mentch L, Brown G, Kazmerski TM, et al. Best practices for virtual engagement of patient-centered outcomes research teams during and after the COVID-19 pandemic: qualitative study. J Particip Med. 2021;13(1):e24966.

31. Godfrey EM, Mentch L. Bringing patient centered outcomes research to the CF community. https://www.youtube.com/watch?v=qfp0uv7vmg M\&t=99s: Cystic Fibrosis Research Institute; 2020. Podcast: 34:58

32. Roberson PK, Shema SJ, Mundfrom DJ, Holmes TM. Analysis of paired Likert data: how to evaluate change and preference questions. Fam Med. 1995;27:671-5.

33. R Core Team. R: a language and environment for statistical computing. Vienna. R Foundation for Statistical Computing; 2020.

34. Mentch L. Patient-centered outcomes research: a new approach for the CF community. CF Roundtable: a newsletter for adults who have cystic fibrosis. 2020 Summer, 2020:56.

35. Fregonese F. Community involvement in biomedical research conducted in the global health context; what can be done to make it really matter? BMC Med Ethics. 2018;19(Suppl 1):44.

36. Lavallee DC, Gore JL, Lawrence SO, Lindsay J, Marsh S, Scott MR, et al. Initiative to support patient involvement in research (INSPIRE): community workshop report. 2016 October 2016.

\section{Publisher's Note}

Springer Nature remains neutral with regard to jurisdictional claims in published maps and institutional affiliations.

- fast, convenient online submission

- thorough peer review by experienced researchers in your field

- rapid publication on acceptance

- support for research data, including large and complex data types

- gold Open Access which fosters wider collaboration and increased citations

- maximum visibility for your research: over $100 \mathrm{M}$ website views per year

At BMC, research is always in progress.

Learn more biomedcentral.com/submissions 